\title{
EVERY GIRL DREAMS OF FALLING IN LOVE
}

\author{
For the good of the nation.
}

\section{BY SHELLY LI}

$\mathrm{E}$ very girl dreams of falling in love. When I was five, I decided that my future husband would have a smile that could brighten a room.

At twelve, I dreamt of a husband who was tall and slim, with dark, clean-cut hair and a well-defined jawline. He would have green eyes that reminded me of evergreen trees.

At sixteen, I wanted to date a guy with blonde curls that swept over his eyes. He would be a witty but tortured soul, perhaps a poet. He would be shy around everyone else, but with me, he would open up and make me laugh, and he would make my skin tingle when he kissed me.

But when I entered the dating world, the faces of all three of the men I once thought I would marry began to fade into the ceiling of my empty bedroom.

The future never turns out the way we think it will: the cruellest thing God ever gave children was the gift of imagination.

Ten years passed, twenty years, and still, I never once got the chance to answer the question: "Will you marry me?".

To this day, the closest I've ever got to a marriage proposal was when a man in a suit knocked on my door and asked: "Will you serve your country?"

This was five days after the bombing of the railroad out of the Wisconsin River Basin. Like everyone, I wanted to help in any way, and so I agreed. Three days later, Bobby came to me. Bobby was a programmed war machine, the newest and the most human-like model ever designed.

"Introduce him to the neighbours," said the man. "Say the two of you eloped. You don't have to do anything except acknowledge your relationship with him, if ever questioned. He'll come home only in the winter, when he needs a place to hide out."

Bobby looked like a classic American hero, straight off the poster. His hair was cut short, and his ears stuck out. His eyes were hazel, and he had big cheeks, and when he smiled, dimples appeared on his face.

He was pretty laid back when we were alone, but around the neighbours, he was plenty charming, and the story we fabricated went off without a hitch. The way he looked at me when other people were watching ... it actually made me feel loved.

I knew that it wasn't real love. Bobby was a robot who went off and fought in nightmarish places when the neighbours thought and I pretended - that he was going on a business retreat.

Living a lie like that, with a husband who was not even a real man, initially I thought I'd be bothered. But when he was away, and I sat around with the other married women on the porch, the lie became the reality.

We're all living a lie in our own way, after all.

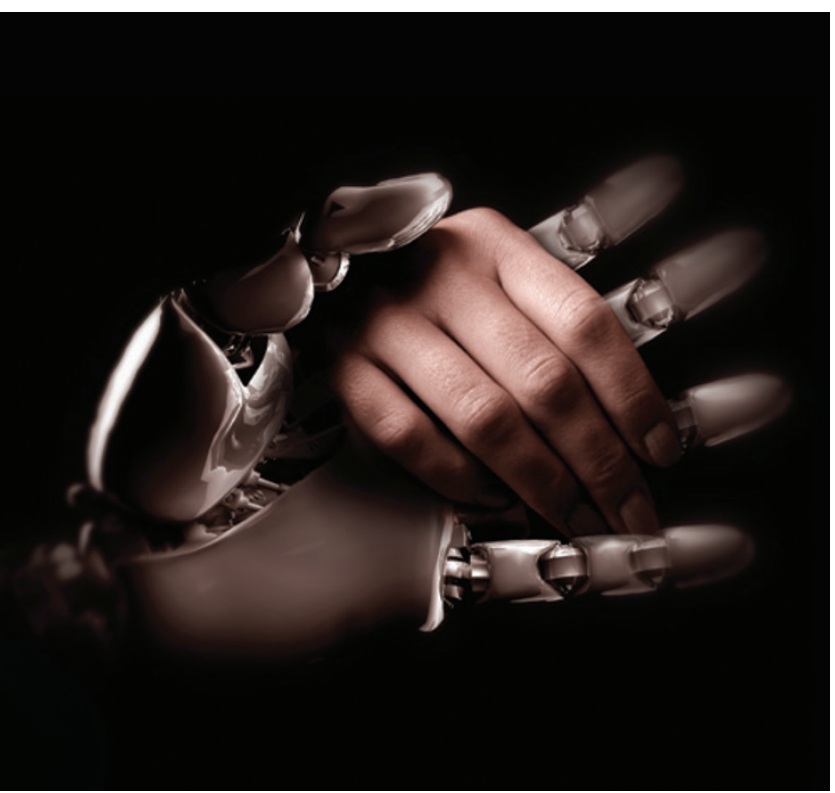

When Bobby came home in the winter, there would never be a scratch on him. The factory repaired him before they let him return, so that no one would see the cuts down his back, or bullet dents up and down his leg.

In this sense, I learned so much from Bobby. He would tell me stories, when we were alone, if I asked. "Bobby's Bedtime Tales," I would jokingly call them. He laughed because he was programmed to laugh when I was laughing, but he didn't understand humour.

I was fascinated by the things he couldn't understand. Sometimes, I would even $\rightarrow$ NATURE.COM

Follow Futures on

Facebook at:

go.nature.com/mtoodm watch him sleep at night. Bobby always slept soundly, even though sleep was probably as foreign to him as gunfire was to me. How could I not love Bobby, even if he couldn't love me back? Bobby would always be the unrecognized hero of the country, the robot that carried out the tasks that humans did not have the stomach to perform.

More years passed and, like clockwork on every December 15th, a taxi would pull up to the driveway, and Bobby would emerge with a big suitcase. He would pretend it was heavy as he lugged it into the house, but it was always empty when he opened it.

The routine was something I had come to accept, no matter how lonely I felt in the springtime, when I saw husbands helping their wives clean out the garage.

It wasn't Bobby's strength that I missed. I could mow my own lawn. I could throw my own steaks on the grill. I could make my own repairs on the house.

It was his company I missed. I missed hearing the breathing of another person, before I drifted off to sleep.

Nevertheless, no matter how many times I whispered under my breath for him to come back, be it spring, summer or autumn, he never returned. I kept telling myself that it was nothing I could change. When I signed up for this, I signed up with the desire to help my country. Somewhere along the way, that desire began to fade just as the faces of my fairytale husbands faded.

One day, I was trimming the tree in the front yard, the one that was tall enough to brush the second-floor windows. The leaves provided a lot of shade in the summer, but it was now autumn, and time for the branches to go.

I climbed to the top of the tree and reached out to clip off a branch. Somehow, my foot slipped, and before I knew it, the grass was zooming towards me.

I stuck out my hands to break the fall, but I ended up knocking into something else before hitting the ground.

Gasping, I blinked and looked up at the man whose arms in which I was cradled.

"Be careful," Bobby said with a smile. nSEE COMMENT P.399

Shelly Li's online home is www.shelly-li. com. Her first novel, The Royal Hunter, will be out this autumn, from Philomel Books. 